\title{
Karakteristik Fisik dan Kimia Telur Burung Mamoa (Eulipoa wallacei) di Pantai Uwo Uwo Kecamatan Galela Kabupaten Halmahera Utara
}

\section{Chemical And Physical Characteristics of Mamoa Egg (Eulipoa Wallacei) In Uwo-uwo Beach, Galela Subdistrict North Halmahera District}

\author{
Yusri Sapsuha $^{1}$, Nur Sjafani ${ }^{1}$, Nurjana Albaar $^{2}$, Hasriani Ishak $^{3}$ \\ ${ }^{1}$ Program Studi Peternakan Fakultas Pertanian Universitas Khairun, Ternate, 97715 \\ ${ }^{2}$ Program Studi Teknologi Hasil Peternakan Fakultas Pertanian Universitas Khairun, Ternate, 97715 \\ ${ }^{3}$ Program Studi Pendidikan Matematika FKIP, Universitas Khairun, Ternate, 97751 \\ Email : yusrisapsuhaunkhair@gmail.com
}

\begin{abstract}
The aim of this research was to determine physicochemical characteristics of Mamoa egg. The eggs were collected about 100 eggs from Uwo uwo beach. Physical quality was observe in Animal Husbandry laboratory, Faculty of Agricultural, Khairun University. The physical characteristics observed were measuring include weight, shape, colour of eggshell, length, diameter, egg index, albumen, yolk, weight of eggshell, haugh unit, and thickness of eggshell. The chemical characteristics consist of moisture content, protein, fat content, fiber content, ash, carbohydrate, cholesterol, and antioxidant. Data were analyzed by quantitative descriptive analysis. The result showed that physical quality of egg were weight $=97.28 \mathrm{~g}$, length $=7.12 \mathrm{~cm}$, diameter $=5.45 \mathrm{~cm}$, index of egg $=71.89 \%$, Percentage of yolk and albumen were $69.12 \%$ and $23.24 \%$, haugh unit score $=68.78$ and shape of egg was ovale. The chemical characteristic of egg chemical quality were protein content $=15.47 \%$, fat content $=8.31 \%$, carbohydrate $=25.52 \%$, cholesterol $=387.54 \mathrm{mg} / 100 \mathrm{gr}$, and antioxidant $=49.08 \% \mathrm{dpph}$.
\end{abstract}

Key words: Mamoa bird, Mamoa egg, Physical characteristic, Chemical characteristic

\begin{abstract}
Abstrak
Tujuan penelitian ini adalah untuk mengetahui karakteristik fisik dan kimia telur burung Mamoa. Sebanyak 100 butir telur mamoa diambil dari pantai Uwo uwo Desa Mamuya Kecamatan Galela, Kabupaten Halmahera Barat, Maluku Utara. Pengamatan dan pengukuran kualitas fisik telur dilakukan di Laboratorium Peternakan Fakultas Pertanian Universitas Khairun. Karakteristik fisik telur yang diamati yaitu bobot, bentuk, warna kerabang, panjang, diameter, indeks telur, putih telur (albumen), kuning telur (yolk), berat kerabang, Haugh Unit (HU), tebal kerabang, dan warna kerabang. Kualitas kimia telur terdiri dari kadar air, protein, lemak, serat kasar, abu, total karbohidrat, kolesterol dan anti oksidan. Data yang diperoleh dianalisis dengan menggunakan analisis deskriptif kuantitatif. Hasil pengukuran kualitas fisik telur Mamoa yaitu berat 97,28 gr, panjang 7,12 cm, diameter 5,45 cm indek telur 71,89\%, persentase putih telur dan kuning telur masing-masing 23,24 dan 69,12\% dengan nilai Haugh Unit 68,78 serta bentuk telur oval. Hasil analisis kimia telur Mamoa yaitu protein 15,47\%, lemak 8,31\%, karbohidrat 25,53\%, kolesterol 387,54 mg/100g serta antioksidan $49.08 \% \mathrm{dpph}$.
\end{abstract}

Kata kunci : Burung Mamoa, Telur Mamoa, Karakteristik fisik, Karakteristik kimia

\section{Pendahuluan}

Pulau Halmahera merupakan salah satu pulau terbesar di Maluku Utara dan sebagai pulau utama yang mencakup bagian terbesar hidupan liar, dengan 210 jenis burung. Sebagian besar spesis burung endemik yang terdapat di Maluku Utara dapat ditemukan di pulau ini yaitu 24 dari 26 spesis burung endemik Maluku (Sujatnika et al., 1995; Bibby et al., 1999). Tiga spesis dari genus Megapodius endemik diantaranya yang terdapat di Maluku Utara yaitu 
Eulipoa wallacei (Megapodius wallacei = Gosong Maluku= Mamoa), Megapodius bernsteinii (Gosong Sula), dan Megapodius freycinet (Gosong Kelam) (Sujatnika et al., 1995). Pantai Uwo-uwo di Kecamatan Galela yang berada di bagian utara Pulau Halmahera merupakan daerah populasi terbesar bagi burung Mamoa. Masyarakat setempat memanfaatkan jenis burung ini dan telurnya sebagai salah satu sumber protein untuk dimakan, juga sebagai sumber mata pencaharian. Kegiatan pemanenan telur yang berlebihan merupakan ancaman bagi populasi burung ini serta dipercepat dengan perambahan hutan, pembukaan lahan untuk pertanian oleh masyarakat setempat sehingga menyebabkan terjadinya degradasi dan fragmentasi lokasi bersarang.

Status populasi burung ini sudah dilindungi berdasarkan Surat Keputusan Menteri Pertanian nomor 757/Kpts/Um/12/1979 tertanggal 5 Desember 1979 (Noerdjito dan Maryanto, 2001). Namun sampai saat ini, lokasi bertelur burung Mamoa di Kecamatan Galela (Kabupaten Halmahera Utara) belum ada suatu keputusan untuk melindungi lokasi burung ini melangsungkan kehidupannya agar dapat terhindar dari ancaman kepunahan. Habitat hidup burung Mamoa berada di pegunungan dengan ketinggian antara $500-2000 \mathrm{~m}$ dpl, sedangkan habitat bertelur di pantai dengan hamparan pasir hitam yang terbuka (Sjafani., et al 2015). Keberadaannya di alam rentan, akibat eksploitasi telur yang berlebihan, perburuan terhadap induk, serta fragmentasi habitat, hal ini mengancam kelangsungan hidup dari satwa tersebut.

Berdasarkan hasil penelitian yang dilaksanakan oleh Heij dan Rompas (1997), bahwa burung Mamoa menggunakan sumber panas matahari di pantai untuk pengeraman telurnya, sedangkan berdasarkan hasil observasi, peneliti berpendapat bahwa tidak semua daerah pantai di kecamatan Galela bisa dijadikan sebagai tempat bertelur dan pengeraman oleh burung Mamoa. Ini diduga karena adanya faktor- faktor pendukung terhadap tempat bertelur. Tempat yang disukai oleh burung Mamoa untuk bertelur dan merupakan faktor kunci meliputi kondisi vegetasi (misalnya; struktur fisik), lokasi yang benar-benar aman, dan daerah yang diapit oleh dua barier. Suhu (temperatur) dan kelembaban merupakan faktor-faktor eksternal yang sangat dibutuhkan untuk kelangsungan hidupnya. Penelitian ini dilakukan untuk mengetahui dan menggambarkan karakteristik fisik dan kimia dari telur burung mamoa.

\section{Materi dan Metode}

Sebanyak 100 butir telur Mamoa yang baru diambil dari pantai Uwo-uwo Desa Mamuya Kecamatan Galela, Kabupaten Halmahera Barat, Maluku Utara. Pengamatan dan pengukuran kualitas fisik telur dilakukan di Laboratorium Peternakan Fakultas Pertanian Universitas Khairun. Karakteristik fisik telur yang diamati terdiri dari beberapa komponen yaitu bobot, bentuk, warna kerabang, panjang, diameter, indeks telur, putih telur (albumen), kuning telur (yolk), berat kerabang, Haugh Unit (HU), tebal kerabang, dan indeks warna yolk. Pengukuran berat telur, panjang, diameter, indeks telur dan warna kerabang, menggunakan 100 butir telur sedangkan untuk pengukuran proporsi putih telur (albumen), proporsi kuning telur (yolk), berat kerabang, Haugh Unit (HU) dan tebal kerabang dilakukan dengan memecahkan 30 butir telur. Analisis kualitas kimia telur menggunakan 5 butir telur dengan komposisi terdiri dari kadar air, protein, lemak, serat kasar, abu, dan total karbohidrat, Analisis proksimat (AOAC, 1984) digunakan untuk mengetahui kualitas kimia telur sedangkan penentuan kadar antioksidan dilakukan dengan menggunakan metode dpph (2,2-diphenyl-lpicrylhydrazyl) assay menurut Ambriz et al. (2008). 


\section{Hasil dan Pembahasan}

\section{Karakteristik fisik telur burung Mamoa}

Hasil penelitian pada Tabel 1 menunjukkan

bahwa berat telur burung Mamoa yaitu pada kisaran $79,25-105,00 \mathrm{~g}$ dengan rata-rata 97,28 $\pm 6,64$, hasil ini lebih kecil 2,25 kali dibandingkan dengan telur Maleo

Kabupaten Halmahera Utara

\begin{tabular}{lcccc}
\hline \multicolumn{1}{c}{ Komponen } & $\mathrm{n}$ & Rerata $\pm \mathrm{S}_{\mathrm{d}}$ & Maksimum & Minimum \\
\hline Bobot $(\mathrm{g})$ & 100 & $97,28 \pm 6,64$ & 105,00 & 79.25 \\
Panjang $(\mathrm{cm})$ & 100 & $7,12 \pm 0,52$ & 8.36 & 6,98 \\
Diameter $(\mathrm{cm})$ & 100 & $5.45 \pm 0.73$ & 5.98 & 5.13 \\
Indeks telur $(\%)$ & 100 & $71.89 \pm 4.12$ & 75.21 & 64.65 \\
Putih telur (\%) & 30 & $23.24 \pm 2.78$ & 27.37 & 21.12 \\
Kuning telur (\%) & 30 & $69.12 \pm 3.18$ & 71.85 & 63.74 \\
Kerabang (\%) & 30 & $8.43 \pm 1.38$ & 9.12 & 7.34 \\
Haugh unit & 30 & $68.78 \pm 4.32$ & 73.54 & 65.00 \\
Tebal kerabang $(\mathrm{mm})$ & 30 & $0.34 \pm 0.18$ & 0.39 & 0.32 \\
Warna kerabang & 100 & \multicolumn{3}{c}{ Coklat tua dan coklat muda } \\
Bentuk telur & 100 & Oval & \\
\hline
\end{tabular}

$\mathrm{n}$ : Jumlah sampel $\mathrm{S}_{\mathrm{d}}$ : Standar deviasi

Jones et al. (1995) menyatakan bahwa persentase berat telur pada megapoda berkisar 13,80$17,60 \%$ dari berat induk. Dekker dan Brom (1990) melaporkan bahwa ukuran telur dari burung Maleo adalah bobot 231,50 $\pm 13,23 \mathrm{~g}$, lebih lanjut dikatakan bahwa ukuran telur burung dipengaruhi oleh beberapa faktor yaitu topografi, iklim, ketersediaan air, dan pakan, jenis vegetasi, ukuran tubuh, dan proses fisiologi.

Hasil penelitian menunjukkan bahwa panjang dan diameter telur burung mamoa yaitu 7,12 $\pm 0,52$ dan $5,45 \pm 0,73 \mathrm{~cm}$. Hasil penelitian ini relatif sama dengan yang dilakukan sebelumnya (Sapsuha, 2013), dimana telur mamoa yang diambil dipantai Tiabo Desa Toweka Kecamatan Galela diperoleh panjang dan diameter masing-masing 7,74 $\pm 0,52$ dan $5,60 \pm 0,20 \mathrm{~cm}$. Hasil penelitian Hafsah (2009) terhadap telur burung maleo yang diambil dari Taman Nasional Lore Rindu Sulawesi Tengah diperoleh hasil panjang 13,27 $\pm 0,17$ $\mathrm{cm}$ dan diameter 9,63 $\pm 0,40 \mathrm{~cm}$, serta hasil penelitian Saerang et al. (2010) terhadap telur burung Maleo yang memiliki berat rata-rata 218,13 g (Hafsah, 2009), $223,70 \mathrm{~g}$ (Saerang et al., 2010) namun termasuk ekstra besar dalam ukuran telur burung atau hampir sekitar 2 kali berat telur ayam petelur 54,03 g (Tugiyanti dan Iriyanti, 2012) dan 61,642 g (Harmayanda et al., 2016). 
69\%, dan Megapoda 65-69\% dari bobot telur.

Heij dan Rompas (1997) melaporkan bahwa pada burung Mamoa (Eulipoa wallaceii) proposi ratarata kuning telur $66,3 \%$ dengan kisaran $65,0-71,4 \%$ dari bobot telur. Sasongko (1990) melaporkan bahwa perbandingan kuning telur pada beberapa jenis unggas seperti: angsa sebesar $38,10 \%$, kalkum $35,40 \%$, entog $45 \%$, itik $36,30 \%$, ayam kampung $39,20 \%$, dan merpati sebesar 31,70\%. Faktor lain yang berpengaruh terhadap kualitas kuning telur adalah kadar lemak (Sell et al. 2002). Penurunan bobot kuning telur dan warna kuning telur dipengaruhi oleh kadar asam lemak linolenat (Omega-3) dalam ransum (Caston dan Leeson, 1990; Elswyk, 1997).

Proporsi kuning telur yang tinggi pada megapoda merupakan suatu kondisi yang diperlukan embrio untuk pertumbuhannya selama periode penetasan (Jones et al., 1995). Kuning telur merupakan sumber nutrien yang digunakan anak burung mamoa setelah keluar dari kerabang, setelah itu anak burung mamoa memerlukan waktu beberapa jam untuk muncul ke permukaan tanah.

Bentuk telur burung mamoa adalah simetris (oval) dan warna kerabang coklat tua dan coklat muda (Gambar 1) dengan tektur kerabang agak kasar. Menurut Mardiastuti (1991), secara umum telur memiliki dua bentuk yaitu bentuk simetris (lebar oval hampir bulat, panjang oval ellips, normal oval) dan asimetris (normal oval, panjang oval, lebar oval). Yuwanta (2002) menyatakan bahwa bentuk telur pada unggas yaitu oval, elliptical, biconial, conial, dan spherical, sedangkan tekstur kerabang terdiri dari kasar, rata licin dan bergaris.

Spesies burung sangat dominan menentukan warna kerabang telur (Larbier dan Leclerecq, 1994). Menurut Welty (1979), warna atau pigmen kerabang ditentukan oleh pigmen hemoglobin dalam darah yang disebut porphyrins sebagai pembawa warna coklat atau olive atau pigmen empedu yang tersimpan dalam hemoglobin yang disebut cyanin yang disekresi oleh empedu sebagai pembawa warna biru atau hijau.

Hasil penelitian seperti tercantum pada Tabel 1 menunjukkan bahwa rata-rata HU telur burung mamoa adalah 68,78 \pm 4,32 dengan kisaran antara 65,00 75,54. Melihat nilai HU dari telur burung mamoa dapat diklasifikasikan menjadi telur grade AAdan A. Sesuai dengan pernyataan Soeparno et al., (2001), besarnya HU dalam klasifikasi kualitas telur yaitu grade AA dengan nilai HU lebih dari 72; grade A dengan nilai HU diantara 56 sampai 72; grade $\mathrm{B}$ dengan nilai $\mathrm{HU}$ antara 31 sampai 55; dan grade C kurang dari 31.

Nilai haugh unit merupakan nilai yang mencerminkan keadaan albumen telur yang berguna untuk menentukan kualitas telur. Nilai haugh unit ditentukan berdasarkan keadaan putih telur, yaitu korelasi antara bobot telur dan tinggi putih telur. Menurut Stadelman dan Cotteril (1977), nilai haugh unit dipengaruhi oleh kandungan ovomucin yang terdapat pada putih telur. Putih telur yang semakin tinggi, maka nilai haugh unit yang diperoleh semakin tinggi. Haugh unit dipengaruhi umur ayam dan genotipnya, musim, kandungan nutrisi pakan, lama dan suhu selama penyimpanan. Umur ayam yang meningkat dan suhu lingkungan di atas $30{ }^{\circ} \mathrm{C}$ menyebabkan penurunan nilai HU (Williams, 1992).

\section{Karakteristik kimia telur Mamoa}

Hasil penelitian menunjukan bahwa komposisi kimia telur burung Mamoa agak berbeda dibandingkan dengan telur ayam atau jenis burung yang lain. Pada Tabel 2 terlihat bahwa komposisi air telur mamoa sebesar 50,68 \% , hasil ini menunjukkan bahwa kandungan air pada telur burung mamoa lebih rendah dari telur ayam merawang sebesar 71,98 \% (Imam Rahayu, 2003), namun relatif sama dengan kandungan air telur burung maleo yaitu sebesar 51,05 \% (Saerang etal., 2010). 
Tabel 2. Komposisi kimia telur burung Mamoa (Eulipoa wallacei) di pantai Uwo uwo Kecamatan Galela Kabupaten Halmahera Utara

\begin{tabular}{lcccc}
\hline Komponen & $\mathrm{n}$ & Rerata $\pm \mathrm{S}_{\mathrm{d}}$ & Maksimum & Minimum \\
\hline Air (\%) & 5 & $50.68 \pm 0.38$ & 51.12 & 49.78 \\
Protein (\%) & 5 & $15.47 \pm 0.64$ & 16.45 & 14.58 \\
Lemak (\%) & 5 & $8.31 \pm 0.87$ & 9.32 & 7.89 \\
Serat kasar (\%) & 5 & $0.02 \pm 0.01$ & 0.02 & 0.01 \\
Abu (\%) & 5 & $1.90 \pm 0.15$ & 2.12 & 1.14 \\
Total kabohidrat (\%) & 5 & $25.52 \pm 0.38$ & 26.13 & 24.17 \\
Kolesterol (mg/100g) & 5 & $387.54 \pm 1.24$ & 388.15 & 386.98 \\
Antioksidan (\% dpph) & 5 & $49.08 \pm 1.72$ & 51.06 & 47.82 \\
\hline
\end{tabular}

$\mathrm{n}$ : Jumlah sampel $\quad \mathrm{S}_{\mathrm{d}}$ : Standar deviasi

Kandungan protein dan lemak telur Mamoa berturut-turut $15,47 \%$ dan $8,31 \%$. ini menunjukkan bahwa kandungan protein dan lemak telur burung Mamoa lebih rendah dibandingkan telur burung Maleo yang memiliki kandungan protein $16,57 \%$ dan lemak $38,89 \%$ (Hafsah, 2009), serta ayam arab dengan kandungan protein 18,74\% dan lemak 33,32\% (Yumna etal., 2013).

Kadar kolesterol telur Mamoa adalah 387,54 $\mathrm{mg} / 100 \mathrm{~g}$ relatif lebih tinggi dibandingkan dengan kadar kolesterol telur ayam 261,80 mg (Harimurti, 1995), 242,72 mg (Larbier dan Leclrcq, 1994), dan pada telur burung unta 109,49 mg (Sahan et al., 2003), dan sedikit lebih rendah dibandingkan telur burung maleo 405,92 (Hafsah, 2009). Tingginya kolesterol pada telur mamoa berhubungan dengan proses

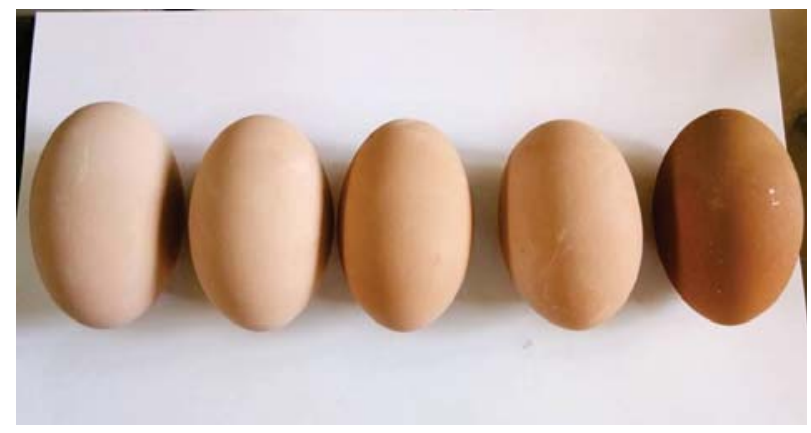

Gambar 1. Telur burung Mamoa (Eulipoa wallacei) (Skala 1:4) pertumbuhan embrio dalam telur yang membutuhkan kandungan mineral yang tinggi untuk pertumbuhan tulang, bulu, kuku, dan komposisi tubuh yang lain.

Kandungan antioksidan telur Mamoa juga tinggi yaitu sebesar $49.08 \%$ dibandingkan dengan telur ayam 9,53\% dan itik 15,7\% (Nahariah et al., 2014) namun sedikit lebih rendah dari telur burung Maleo yaitu sebesar 52,34\% (Hafsah, 2009). Tingginya kandungan antioksidan telur burung Mamua disebabkan karena pakan yang dikonsumsi oleh burung Mamoa di habitatnya kebanyakan dari jenis biji-bijian (Sjafani. et al., 2015), karena unggas yang banyak mengkonsumsi pakan biji-bijian akan menghasilkan telur yang mengandung antioksidan tinggi (Nirmalaratne et al., 2011). Menurut Pajak et al., (2013) bahwa apabila ternak unggas diberi pakan yang mengandung biji-bijian terutama yang berkecambah maka kandungan antioksidan dalam telurnya akan tinggi karena selama proses perkecambahan terjadi peningkatan kandungan senyawa antioksidan seperti vitamin dan polifenol.

Santoso (2006) menyatakan bahwa apabila dalam suatu bahan mengandung antioksidan yang tinggi maka dapat menunda atau menghambat oksidasi substrat tersebut, karena antioksidan efektif meningkatkan daya simpan berbagai produk makanan. 
Hal tersebut mengindikasikan bahwa dengan penyimpaanan yang lama telur burung Mamoa dapat bertahan tanpa mengalami pembusukan. Namun seberapa lama penyimpanan sampai mengalami pembusukan pada telur burung Mamoa merupakan obyek yang menarik karena belum ada hasil penelitian yang mengkaji hal tersebut.

\section{Kesimpulan}

Telur Mamoa yang diperoleh dari pantai Uwo uwo di Desa Mamuya, Kecamatan Galela, Kabupaten Halmahera Utara memiliki bentuk telur yang simetris (oval) dan warna kerabang coklat tua dan coklat muda dengan tektur kerabang agak kasar, kandungan protein dan lemak yang rendah namun kandungan kolesterol dan antioksidan lebih tinggi dibanding dengan telur ayam.

\section{Ucapan Terima Kasih}

Ucapan terima kasih disampaikan kepada Kementerian Riset, Teknologi dan Pendidikan Tinggi Direktorat Pengembangan Teknologi Industri atas bantuan biaya penelitian Insentif Riset Sistem Inovasi Nasional(INSINAS) tahun 2016.

\section{Daftar Pustaka}

Ambriz, S. L. R., J. J. I. Hernandes, E. A. Acevedo, J. Tovar, and L. A. B. Peres. (2008). Characterization of a fibre-rich powder prepared by liquefaction of unripe banana flour. Food Chemistry 107: 1515-1521.

AOAC,(1984). Official Methods of Analysis. 12th. ed. Associationof Official Analysis Chemist. Washington D.C.

Biby, C., S. Marden and A. Fielding. (1999). BirdHabitat Studies. The Expedition Advisory Centre. Royal Geographical Society. London.

Caston, L. dan S. Leeson. (1990). Dietary flax and egg composition. J. Poultry. Sci. 69: 1617-1620.
Elswyk, M.E.V. (1997). Nutritional and physiologycal effects of flax seed in diets for laying fowl. World's Poultry. Sci. J. 53: 253-264.

Dekker, R.W.R. J. and T.G. Brom. (1990). Maleo Eggs And The Amount of Yolk in Relation to Different Incubation Strategies in Megapodes. Autralian Journal of Zoology 38:19-24

Hafsah. (2009). Percepatan Peningkatan Populasi Burung Maleo (Macrochephalon maleo) Melalui Perbaikan Pola Penetasan dan Penangkaran di Taman Nasional Lore Lindu Sulawesi Tengah. Disertasi. UGM. Yogyakarta.

Harimurti, S. (1995). Upaya menurunkan kadar kolesterol telur dengan suplementasi vitamin $\mathrm{C}$ pada ransum petelur berenergi tinggi. Buletin Peternakan. Vol. 19:159-166

Harmayanda, P.O.A., D. Rosyidi, and O. Sjofjan. (2016). Evaluasi Kualitas Telur Dari Hasil Pemberian Beberapa Jenis Pakan Komersial Ayam Petelur. J-PAL, Vol. 7 (1):25-32

Heij, C.J. dan C.F.E. Rompas. (1997). Ekologi Megapoda Maluku (Burung Momoa, Eulipoa wallacei) Di Pulau Haruku dan Beberapa Pulau Di Maluku, Indonesia. Rotterdam/Ambon.

Imam Rahayu, H.S. (2003). Karakteristik Fisik, Komposisi Kimia dan Uji Organoleptik Telur Ayam Merawang dengan Pemberian Pakan Bersuplemen Omega-3. Jurnal Teknol. dan Industri Pangan Vol XIV (3): 199-205

Jones, D.N., R.W.R.J. Dekker and C.S.Roselaar. (1995). Bird Families of The World. The Megapodes. Oxford University Press.

Larbier, M. and B. Leclercq. (1994). Nutrition and Feeding of Poultry. INRA. University Press, Nottingham.

Mardiastuti, A. (1991). Difference in size among waterbirds eggs in Pulau Rambut: Some Preliminary Observation. Media Konservasi III (2):66-77

Nahariah, A.M Legowo, E. Abustam, A. Hintono, P. Bintoro dan Y.B. Pramono. 2014. Endogeneous antioxidant activity in the egg whites of various types of local poultry eggs in South Sulawesi, Indonesia. Int. J. Poultry Science. 13(1):21-25 
Nirmalaratne, C., D.L. Lutz, A. Schieber and J. Wu, (2011). Free aromatic amino acids in egg yolk show antioksidan properties. Food Chem., 129: $155-161$.

Noerdjito, M. dan I. Maryanto. (2001). Jenis-Jenis Hayati yang Dilindungi Perundangundangan Indonesia. Balitbang Zoologi Puslitbang Biologi LIPI Cibinong.

Pajak, P., R. Socha, D. Galkowska, J. Roznowski and T. Fortuna. 2013. Phenolic profile and antioxidant activity in selected seeds and sprouts. Food Chem., 143: 300-306.

Saerang, J.L.P., W. Manalu., I.R.H. Soesanto and A. Mardiastuti. (2010). Physical and Chemical Characteristics of Maleo Egg in Bogani Nani Wartabone Park.. J. Animal Production 12 (1):34-38

Sahan, U., O. Altan, A. Ipek and B. Yilmaz. (2003). Effects of some egg characteristics on the mass loss and hatchability of ostrich (Stuthio camelus) eggs. British Poultry Science Vol.44(3):380-383

Santoso, U. (2006). Antioksidan. Sekolah Pascasarjana Universitas Gadjah Mada, Yogyakarta

Sapsuha, Y. (2013). Kualitas Fisik Telur Burung Mamoa (Eulipoa wallacei). JITP Vol. 2 (3):167-174

Sasongko, H. 1990. Perbandingan sifat fisik telur berbagai jenis uanggas. Laporan Penelitian. Fakultas Peternakan Universitas Gadjah Mada, Yogyakarta

Sell, J.L., C.R. Angel dan F. Escribano. (2002). Influence of supplemental fat on weights of eggs and yolks during early egg production. J. poult. Sci. 66: 1807-1812.

Soeparno, Rihastuti, Indratiningsih, S. Triatmojo, (2001). Dasar Teknologi Hasil Ternak. Jurusan Teknologi Hasil Ternak, Universitas Gadjah Mada, Yogyakarta.
Stadelman, W. J. and O. J. Cotterill. (1977). Egg Science and Technology. $2^{\text {nd }}$ edition. The AVI Publishing Company, INC, Westport, Connecticut

Sujatnika, P. Jepson, Soehartono T.R., Croeby M.J., dan A. Mardiastuti. (1995). Melestarikan Keanekaragaman Hayati Indonesia: Pendekatan daerah endemik. Birdlife Internasional-Indonesia Program. Jakarta.

Sjafani N, Hakim L, Nurgiartiningsih V.M.A, and Suyadi. (2015). The habitat and estimation population of mamoa bird (Eulipoa Wallacei) in Galela-Halmahera. Journal of Biodiversity and Environmental Sciences. Vol. 7, No. 2, p. 01-09.

Tugiyanti, E dan N. Iriyanti. (2012). Kualitas eksternal ayam petelur yang mendapat ransum dengan penambahan tepung ikan fermentasi menggunakan isolate produser antihistamin, Jurnal Aplikasi Teknologi Pangan Vol. 1 (2):44-47

Welty, J. C. (1979). The Life of Birds. Second Edition. Saunders College Publishing. Philadelphia.

William, K.C. (1992). Some factors affect-ing albumen quality with particu-lar reference to Haugh unit score. World's Poultry Science Journal. $48: 5-16$.

Yumna, M.H., A. Zakaria dan V. M. A. Nurgiartiningsih. (2013). Kuantitas dan kualitas telur ayam arab (Gallus turcicus) silver dan gold. J. Ilmu-Ilmu Peternakan 23 (2):19-24

Yuwanta,T. (2002). Telur dan Produksi Telur. Bahan Ajar. Fakultas Peternakan Universitas Gadjah Mada, Yogyakarta 